\title{
Development of Tax Procedural Law and Sectoral Case Law in Selected Countries ${ }^{1}$
}

\author{
Tjaša Vozel \\ vozeltjasa@gmail.com
}

\section{ABSTRACT}

The purpose of this paper is to examine the development of the Slovenian Tax Procedure Act and amendments thereto until 2017, in order to broaden the field knowledge on tax procedures within the administrative system as a whole. The Tax Procedure Act provides the general framework of the procedural tax system in Slovenia. The first version of the Tax Procedure Act (ZDavP) was adopted in 1996 and followed by five amending acts until the adoption of the second version (ZDavP-1) in 2004. The third and currently applicable version of the Tax Procedure Act (ZDavP-2) has been subject to over ten amendments so far. Furthermore, the study aims to compare the development of tax procedure in Slovenia and Sweden. Based on the normative and comparative analyses, review of domestic and foreign literature, and case law analysis, the advantages and disadvantages of the development of tax procedure in Slovenia were identified. The amendments analysed contributed mainly to simplifying the tax procedure, reducing red tape, decreasing costs, improving the efficiency of the tax authorities, and providing greater legal certainty for the taxpayers. Most changes to the Tax Procedure Act involved the personal income tax. An empirical study of the case law of the Administrative, Supreme and Constitutional Courts in selected period further showed that errors were mainly detected in relation to substantial violation of procedural requirements rather than incorrect application of substantive law. The study contributes to administrative and legal science and the tax profession as such. The results can be useful when drafting new tax procedural legislation to improve its effectiveness.

Keywords: case law, development of tax procedure, legislative amendments, Slovenia, Tax Procedure Act, tax procedural law

1 This article is adapted from the Master's thesis of Tjaša Vozel: Razvoj davčnega procesnega prava in področne judikature v izbranih državah [Development of tax procedural law and sectoral case law in selected countries], defended at the Faculty of Administration of the University of Ljubljana on 20 June 2017, under the mentorship Prof. Polonca Kovač, PhD. 


\section{Introduction}

One of the acts most often amended in Slovenia is the Tax Procedure Act (hereinafter: the ZDavP). Ever since its adoption, the Act has been amended numerous times and often even subject to constitutional review. The ZDavP regulates the calculation, assessment, payment, repayment, control and execution of taxes, the rights and obligations of taxable persons, state and other bodies collecting taxes in accordance with the law, and other persons in the procedure of tax collection, the protection of data obtained in the procedure of tax collection, and mutual assistance in the collection of taxes and exchange of information with other EU Member States, third countries and territories (Article 1 of ZDavP-2). Tax authorities and bearers of public authority must comply with the ZDavP when collecting taxes.

The ZDavP was adopted by the National Assembly of the Republic of Slovenia on 20 March 1996 and published in the Official Gazette of the Republic of Slovenia on 2 April 1996. Before the adoption of the ZDavP, the procedures relating to tax and other obligations of taxable persons were regulated by various regulations. Considering such variety of legal bases, the tax procedure lacked transparency for both the tax authorities and the taxable persons. The adoption of the ZDavP in 1996 enabled to unify all procedural provisions in the tax area (Šircelj, 2000, p. 31). Before that, Slovenia had no specific law regulating tax procedure at all.

Owing to EU accession, Slovenia was obliged to transpose the substantive provisions of EU directives into its national legislation also in the field of taxation and had to ensure an appropriate legal basis for tax collection procedures and effective mutual assistance in calculating tax and monitoring regularity (DURS, 2004). Hence, a new Tax Procedure Act - the ZDavP-1 (Official Gazette of the Republic of Slovenia, No. 54/04) - was adopted on 23 April 2004. The ZDavP-1 was first amended by the ZDavP-1A, which was adopted on 16 December 2004 and entered into force on 1 January 2005. Later on, it was amended one more time by the ZDavP-1B, which was adopted on 23 November 2005.

Eventually, on 26 October 2006, the National Assembly of the Republic of Slovenia adopted a third Tax Procedure Act - the ZDavP-2. The latter was published in the Official Gazette of the Republic of Slovenia No. 117/06 as one of the acts adopted in the framework of the tax reform. The purpose of the tax reform was to bring the Tax Procedure Act closer to the implementers and the addressees and eliminate the deficiencies of the existing tax system (Višnjevec, 2007, App. pp. II-VI). To date, the ZDavP-2 has been amended by the following: ZDavP-2A, ZDavP-2B, ZDavP-2C, ZDavP-2D, ZDavP-2E, ZDavP2F, ZDavP-2G, ZDavP-2H, ZDavP-2I, and finally, ZDavP-2J.

The amendments to the ZDavP were generally aimed at simplifying the procedures, especially for the benefit of taxable persons, and making the work of tax authorities easier and simpler. The constant changes, however, make the work of the tax authorities in tax procedures more complicated as they 
cause confusion regarding the application of the right substantive regulation, meaning that a substantive regulation might not have been applied at all, might have been misapplied or misinterpreted, or the authority deciding at discretion might have exceeded the purpose and extent of discretion. Therefore, good practices from abroad need to be considered, as they can show the pros and cons of constantly changing tax laws.

The study tested the following statements: 1) whether since 1996 the changes to the Tax Procedure Act have mostly affected the institution of tax execution; 2) whether after such changes the development of tax procedural law in Slovenia is comparable to the one in Sweden; and 3) whether, considering publicly available court cases of the Administrative, Supreme and Constitutional Courts in tax matters in 2014 and 2015, more errors concerned the incorrect application of substantive law rather than violation of procedural requirements.

The reason for choosing Sweden as a comparative country is that Slovenia often takes Sweden as an example and strives to follow its development. Sweden is a highly developed country but has achieved prosperity only in recent decades. In 1991, it experienced a major financial crisis but picked itself up again to become one of the most developed countries, inspiring many EU members (cf. Terra, 2012). Its highly efficient economy ranks Sweden among the ten leading countries of the world by national income per capita. This also means that it hardly suffered from the financial crisis of 2008, while Slovenia recorded a significant downturn. Over the past two decades, Sweden implemented a series of market-oriented economic reforms, becoming the most economically viable country of the EU.

The article first presents the methodology of research, followed by a graphic and descriptive presentation of results. At the end, some general conclusions are drawn and possible further research in this area suggested.

\section{Methodology}

Several scientific and research methods were applied in the study. The descriptive method served to indicate and describe individual facts and concepts. The analytical method was applied to the content of written and internet sources for analysing legislation, scientific literature, internet articles, and case law. The compilation method was used to summarise the views and conclusions of individual authors. The comparative method allowed to compare similar facts and identify the differences (especially when reviewing and critically comparing the legislation of selected countries). The deductive method was used to confirm or reject the statements made, while the analytical-synthetic method was applied in the analysis of court judgments.

The study analysed all amendments to the Tax Procedure Act since the adoption of the first ZDavP. The amending acts were examined by individual institutions of the tax procedure, namely by the number of articles that had been changed, added or deleted. The analysis covered the most important 
and most comprehensive institutions of the tax procedure: data protection, tax liability, tax procedure, legal remedies, fulfilment of tax obligations, tax supervision, tax execution, international cooperation in tax matters, personal income tax, and penal provisions.

The analysis of the judgments of the Administrative, Supreme and Constitutional Courts in tax matters in 2014 and 2015 and concerning the incorrect application of substantive law and procedural violations is based on the judgments of the above courts issued in 2014 and 2015 and relating to decisions in tax matters. In total, 223 Administrative Court judgments of 2014 and 174 of 2015, and 13 Supreme Court judgments of 2014 and 25 of 2015 were examined. The Constitutional Court only dealt with one constitutional complaint in the агеa of taxes in 2014 and 2015, respectively. As regards the Constitutional Court, only constitutional complaints accepted by the Court for consideration were taken into account.

The judgments of the Administrative and Supreme Courts were obtained from the website www.sodnapraksa.si, which is the website of the Slovenian Judiciary. Its databases contain decisions, positions, principled legal opinions and legal opinions of the Supreme Court, decisions of higher courts, courts of general and special jurisdiction and the Administrative Court, decisions on the assessment of fair financial compensation for non-material damage, and summaries of scientific articles selected by the Supreme Court Records Department. The collection of case law does not contain decisions of the courts of first instance (Sodna praksa, 2013). The judgments of the Constitutional Court were obtained from its website where all decisions issued in matters under the competence of the Constitutional Court since 1991 are available.

\section{Results}

\subsection{Analysis of amendments introduced by ZDavP, ZDavP-1 and ZDavP-2}

As far as ZDavP-1 is concerned, most of the articles amended, added or deleted under the amending acts ZDavP-1A and ZDavP-1B related to personal income tax (24 in total). 23 amendments concerned tax liability, while 18 articles were amended, deleted or added in the area of tax execution. Both amending acts introduced changes in the area of personal income tax: the ZDavP-1A added a new article, while the ZDavP-1B introduced as many as 23 amendments to personal income tax. The institution of tax liability was again affected by both amending acts, with the ZDavP-1A introducing 6 changes and the ZDavP-1B bringing about 17. In the area of tax execution, the ZDavP$1 \mathrm{~A}$ introduced 4 amendments and the ZDavP-1B 14. Most changes were brought about by the ZDavP-1B.

As regards the ZDavP-2, the analysis showed that most changes were again introduced in the field of personal income tax, namely 118. Slightly less, 106, involved international cooperation in tax matters, and 63 concerned tax exe- 
cution. As regards personal income tax, most amendments (35) were brought about by the ZDavP-2F. This is followed by the ZDavP-2B (28 amendments) and the most recent amending act, the ZDavP-2J (24 amendments). International cooperation in tax matters was amended the most by the ZDavP-2E, followed by the ZDavP-2B. Tax execution was mostly affected by the ZDavP2I (20 amendments), while the ZDavP-2B brought about 16 amendments in the area of personal income tax. The analysis also showed that, overall, most amendments were introduced by the ZDavP-2B (the analysis was carried out before the adoption of the ZDavP-2K in December 2017, therefore the latter was not included). On 28 February 2018, the Official Gazette of the Republic of Slovenia No. 13/2018 published the Act Amending the Public Finance Act (ZJF-H), which annulled the sixth paragraph of Article 23 of the ZDavP-2, whereby the reporting on the state and trends in the tax debt of business entities, as defined by the sixth paragraph of Article 23 of the ZDavP-2, was systematically regulated by the Public Finance Act, since it is not a matter of tax procedure but rather an issue to be regulated by the Public Finance Act.

\subsection{Analysis of judgements}

The analysis of the judgments of the Administrative, Supreme and Constitutional Courts in tax matters in 2014 and 2015 was carried out to investigate the incorrect application of substantive law and violations of procedural provisions. The aim of the analyses was to test the question raised in the introduction of the survey, namely that the publicly available court cases of the Administrative, Supreme and Constitutional Courts in tax matters in 2014 and 2015 suggest that most errors were detected regarding incorrect application of substantive law, rather than violation of procedure.

The table below presents the analysis of the judgments of the Administrative Court in tax matters in 2014 and 2015 regarding the incorrect application of substantive law, violation of procedural provisions, and erroneous and incomplete determination of facts.

Table 1: Judgements of the Administrative Court in tax matters in 2014 and 2015

\begin{tabular}{|l|c|c|c|c|}
\hline & \multicolumn{2}{|c|}{$\begin{array}{c}\text { Administrative Court } \\
\text { judgements in 2014 }\end{array}$} & \multicolumn{2}{|c|}{$\begin{array}{c}\text { Administrative Court } \\
\text { judgements in 2015 }\end{array}$} \\
\hline & $\begin{array}{c}\text { Action } \\
\text { dismissed }\end{array}$ & $\begin{array}{c}\text { Action } \\
\text { upheld }\end{array}$ & $\begin{array}{c}\text { Action } \\
\text { dismissed }\end{array}$ & $\begin{array}{c}\text { Action } \\
\text { upheld }\end{array}$ \\
\hline $\begin{array}{l}\text { Erroneous or incomplete } \\
\text { determination of facts }\end{array}$ & 126 & 7 & 66 & 4 \\
\hline $\begin{array}{l}\text { Incorrect application of } \\
\text { substantive law }\end{array}$ & 137 & 20 & 126 & 10 \\
\hline $\begin{array}{l}\text { Substantial violation of } \\
\text { procedural provisions }\end{array}$ & 143 & 15 & 86 & 16 \\
\hline
\end{tabular}

Source: own presentation 
Comparatively speaking, the actions brought before the Administrative Court in 2014 and 2015 were more often dismissed than upheld. In 2014 and 2015, the court dismissed 126 and 66 actions, respectively, filed by the plaintiff on grounds of erroneous and incomplete determination of facts. Such actions were upheld only in 7 cases in 2014 and 4 cases in 2015. As regards actions filed for incorrect application of substantive law in the tax procedure, the Administrative Court in 2014 upheld the action in 20 cases and dismissed it in 137 cases: in 2015, it dismissed the action in 126 cases and upheld it in 10 cases, which is less than a year before. In case of substantial violation of procedural provisions, 15 actions were upheld in 2014 (143 dismissed) and 16 were upheld in 2015 (86 dismissed).

In 2014, most actions were filed due to substantial violation of procedural provisions, while in 2015 most cases concerned incorrect application of substantive law. The least actions were filed due to erroneous and incomplete determination of facts, in 2014 and 2015 alike. Most of the actions dismissed in 2014 involved substantial violation of procedural provisions, and the least actions dismissed in 2015 concerned erroneous and incomplete determination of facts. Most of the actions were upheld in 2014 due to incorrect application of substantive law. Most of the actions filed in grounds of substantial violation of procedural provisions were upheld in 2015.

The following table presents an analysis of the judgements of the Supreme Court in tax matters in 2014 and 2015 concerning the incorrect application of substantive law and substantial violation of procedural provisions.

Table 2: Judgements of the Supreme Court in tax matters in 2014 and 2015

\begin{tabular}{|l|c|c|c|c|}
\hline & \multicolumn{2}{|c|}{$\begin{array}{c}\text { Supreme Court } \\
\text { judgements in 2014 }\end{array}$} & \multicolumn{2}{|c|}{$\begin{array}{c}\text { Supreme Court } \\
\text { judgements in 2015 }\end{array}$} \\
\hline & $\begin{array}{c}\text { Review } \\
\text { dismissed }\end{array}$ & $\begin{array}{c}\text { Review } \\
\text { upheld }\end{array}$ & $\begin{array}{c}\text { Review } \\
\text { dismissed }\end{array}$ & $\begin{array}{c}\text { Review } \\
\text { upheld }\end{array}$ \\
\hline $\begin{array}{l}\text { Incorrect application of } \\
\text { substantive law }\end{array}$ & 12 & 1 & 21 & 4 \\
\hline $\begin{array}{l}\text { Substantial violations of } \\
\text { the provisions governing } \\
\text { administrative dispute procedures }\end{array}$ & 11 & 0 & 16 & 4 \\
\hline
\end{tabular}

Source: own presentation

Table 2 shows that in 2014, the Supreme Court dismissed the review requested because of incorrect application of substantive law in 12 cases and upheld it in one case. In 2015, it dismissed the review as unfounded in 21 cases and upheld it in 4 cases. Comparing the two years, more requests for review were lodged in 2015 than in the previous year. As regards the substantial violation of the provisions governing administrative dispute procedures, the Supreme Court dismissed all 11 reviews in 2014. In 2015, the Supreme Court dismissed 16 reviews as unfounded and upheld 4. 
In 2015, most dismissals concerned reviews requested because of incorrect application of substantive law. Similarly, in 2015, most reviews were dismissed in case of substantial violation of the provisions governing administrative dispute procedures. In 2014, only one review was upheld, namely for incorrect application of substantive law, while in 2015 review was upheld in 4 cases of violation of procedural provisions and in the same number of cases for incorrect application of substantive law.

Table 3 presents an analysis of the judgements of the Constitutional Court in tax matters in 2014 and 2015 concerning the incorrect application of substantive law and violation of procedural provisions.

Table 3: Judgements of the Constitutional Court in tax matters in 2014 and 2015

\begin{tabular}{|l|c|c|c|c|}
\hline & \multicolumn{2}{|c|}{$\begin{array}{c}\text { Constitutional Court } \\
\text { judgements in 2014 }\end{array}$} & \multicolumn{2}{c|}{$\begin{array}{c}\text { Constitutional Court } \\
\text { judgements in 2015 }\end{array}$} \\
\hline & $\begin{array}{c}\text { Constitutional } \\
\text { complaint } \\
\text { rejected }\end{array}$ & $\begin{array}{c}\text { Constitutional } \\
\text { complaint } \\
\text { granted }\end{array}$ & $\begin{array}{c}\text { Constitutional } \\
\text { complaint } \\
\text { rejected }\end{array}$ & $\begin{array}{c}\text { Constitutional } \\
\text { complaint } \\
\text { granted }\end{array}$ \\
\hline $\begin{array}{l}\text { Erroneous and incom- } \\
\text { plete determination of } \\
\text { facts }\end{array}$ & 0 & 0 & 0 & 0 \\
\hline $\begin{array}{l}\text { Incorrect application of } \\
\text { substantive law }\end{array}$ & 0 & 0 & 1 & 0 \\
\hline $\begin{array}{l}\text { Substantial violation of } \\
\text { procedural provisions }\end{array}$ & 0 & 1 & 0 & 0 \\
\hline
\end{tabular}

Source: own presentation

As shown by Table 3, only one constitutional complaint in the field of tax matters was accepted for consideration in both 2014 and 2015. The constitutional complaint in 2014 (No. U-l-234/12) was granted. This complaint was filed - together with the motion to initiate the procedure for assessing the constitutionality of the sixth paragraph of Article 57 of the ZDavP-2 - in relation to the deprivation of the plaintiff's right to a fair trial, right to legal remedy, and right to judicial protection. The Constitutional Court annulled the challenged judgments of the Supreme and Administrative Courts and returned the case to the Administrative Court for a new decision, since the plaintiff was deprived of the guarantee of equal protection of rights enshrined in Article 22 of the Constitution. He was in fact deprived of the right to be heard in the procedure in which his rights and obligations were decided.

The constitutional complaint of 2015 was not granted. This case actually comprised two constitutional complaints (No. UI-129/13-16 and UI-138/13-16) filed by the same plaintiff together with the motion to initiate the procedure for assessing the constitutionality of the second paragraph of Article 11 of the Motor Vehicle Tax Act (Official Gazette of the RS, No. 52/99). The constitutional complaints were filed for infringement of equality before the law re- 
ferred to in the second paragraph of Article 14 of the Constitution, equal protection of rights referred to in Article 22 of the Constitution, free economic initiative referred to in Article 74 of the Constitution, and the principle of the free movement of goods under Article 28 of the Treaty on the Functioning of the European Union (TFEU, consolidated version, OJ C 326, 26 October 2012). The Constitutional Court ruled that the provision of the Motor Vehicle Tax Act was not inconsistent with the alleged infringements of the Constitution, and therefore rejected the challenged decisions on which the constitutional complaint was based.

\subsection{Comparison with the development of tax procedure in Sweden}

For much of the $19^{\text {th }}$ century, Sweden was one of the poorest countries in Europe. Economic growth was spurred by a wave of free trade reforms. In 1970, Sweden ranked fourth in terms of GDP per capita among the OECD countries. In the 1970s and 1980s, it raised its tax wedge from the European average to one of the highest in Europe. The public sector expanded widely. In 1990, Sweden suffered a major economic crisis that brought it down to the $14^{\text {th }}$ place among the OECD countries. Its successful exit from the crisis in 1991 was due to what is known as the 'tax reform of the century' (more in Lodin, 2011).

At that time, the Swedish tax system was dominated by an increasing number of specific solutions, rules and exceptions. Before that, the tax system had been posing major barriers to work and investment. One of the reasons for this was that individuals with similar income were taxed differently. Similarly, the tax rates on capital gains from interest on savings or dividends were significantly higher than capital gains. The VAT rates also differed greatly, depending on the product and service. This led to a reduction of the tax base and undermined the legality of the entire system. With the tax reform of 1991, Sweden obtained wider tax bases and tax rates were adjusted. The tax collection system became transparent, uniform and legitimate (Forsberg \& Brännström, 2010).

The reform of 1991 can also be considered the 'most far-reaching reform of the tax system of a nation for at least 40 years'. Impartiality or neutrality was replaced by social and economic engineering and income distribution as one of the key principles of fiscal policy. This revolution is also reflected in the tax reforms adopted in 1985, 1991 and 1994. Since 1991, several important additional reforms have been adopted with regard to taxation of income from capital. At the beginning of 1992, the tax rate for capital gains was reduced from $30 \%$ to $25 \%$. Similarly, at the beginning of 1994 , corporate income tax was reduced from $30 \%$ to $28 \%$, and the tax deduction on dividends for new shares was abolished (Norman \& McLure, 1997, p. 109).

Sweden is known for its extremely high taxes, which its residents nevertheless happily and conscientiously pay. They do not mind the high taxes because they know that these ensure better health and social care. Given that the word 
'tax' has such a negative connotation for many people around the world, it is likely to expect that a government agency that takes about a third of the average monthly salary would be the number one enemy in Sweden. Yet this is not the case. The Swedish tax agency - Skatteverket - is, in Fact, quite popular among the Swedish population. The Swedes consider it a trusted and respectful agency. As Toivo Sjörén would say, 'you don't have to like taxes, but most people seem confident that things are done fairly' (Willes, 2016). In Sweden, the bodies in charge of the tax system are the Ministry of Finance and the Skatteverket. The proposals for tax legislation and health insurance contributions are prepared by the Ministry of Finance, while the tax agency is responsible for the operational aspect of taxation.

In terms of state organisation, Sweden is a constitutional monarchy. Tax law and other legislation are enacted by the Parliament. The constitutional basis for taxation can be found in the 'Instrument of Government', which is one of the four basic laws that make up the Swedish Constitution. It contains basic political principles governing the state and defines and restricts the powers of the Swedish Government. The principle that all taxes must be in accordance with the law is expressed in Article 3 of Chapter 8 of the Instrument of Government. Additional tax provisions are found in Chapter 2, dealing with fundamental rights and freedoms. The Swedish tax system comprises almost all types of taxes. Each tax is regulated by a special act, while administrative and procedural rules are regulated by further separate laws. The rules governing the assessment, tax return and payment of taxes are set out in three different legal acts: the Tax Assessment Act, the Payments Tax Act, and the Self-Taxation and Reporting of Income Act (more in Lindencrona, 2010).

The comparison between tax systems in Slovenia and Sweden suggests that the two share a similar tax policy. They both have a body that oversees the collection of taxes: the Tax Agency in Sweden and the Financial Administration in Slovenia (hereinafter: FURS). In Sweden, the Agency enjoys considerable public support and trust, while trust in the FURS is low or even negative.

The legal basis for the conditions and methods of collecting taxes in both countries is determined by individual tax laws. The method of fulfilling tax obligations in Slovenia is determined by the ZDavP-2, while in Sweden administrative and procedural rules are determined by three different legal acts: the Tax Assessment Act, which sets out the procedural rules for the assessment of larger taxes, the Self-Taxation and Reporting on Income Act, which sets out the rules for self-taxation of taxable persons and the reporting on income paid by, for example, employers, banks, insurance companies, etc., and the Payments Tax Act, which provides the basis for organisation, advance payments, final payment, and withholding tax.

One of the main differences between Sweden and Slovenia is the population's attitude towards taxes. If in Sweden high taxation is something completely acceptable, it is all but so in Slovenia. The Swedish population is aware that high taxes are needed to ensure prosperity, such as health and social care. In exchange for high taxes, the Swedes receive some sort of equity and the 
assurance that their money will not be allocated for unnecessary purposes. Therefore, there is no negative feeling about paying high taxes. One could even say that taxpayers in Sweden are better off than in Slovenia, as Sweden is considered a country with the most optimal tax system in Europe.

\section{Discussion}

The Tax Procedure Act, the amendments thereto, the relevant amending acts, and the advantages and disadvantages of the amendments were dealt with in numerous articles published in professional journals (Uprava, Pravna praksa, Podjetje in delo) by various authors (Kovač, Jerovšek, Višnjevec, etc.), in some Master's theses, and other sources, especially the internet (the Tax-Fin-Lex portal). In her Master's thesis of 2012, Helena Truden studied the development of the protection of the rights of taxpayers in the Slovenian tax procedure, presenting the tax procedure, its particularities, and whether tax legislation changed over the years to the benefit or to the detriment of taxable persons.

The Master's thesis of Sonja Kutnjak (2015) contained a procedural analysis of the protection of the persons liable to income tax in Slovenia and Croatia, taking into account all amendments. In 2014, Petra Kmetič analysed the fiscal measures and legislation of selected countries, Slovenia included, in 20072013. However, the numerous sources relating to the ZDavP only emphasised certain amendments thereto or certain institutions of the tax procedure, as we could not find that a single piece of work presenting a comprehensive chronological development of the ZDavP and analysing the changes introduced by each new Act to the institutions of the tax procedure.

Our analysis showed the advantages and disadvantages of all the changes affecting the ZDavP and the institutions of tax procedure over the years. The analysis also answered the question whether the many changes were positive and contributed to a better development of the tax procedure in Slovenia.

The purpose of the first analysis was to verify whether the development of the ZDavP brought the most changes in the field of tax execution and what these changes were. Tax execution is an extreme measure that the Financial Administration uses if a debtor fails to fulfil their monetary liabilities within the deadlines prescribed for voluntary fulfilment. As a result of the economic crisis, the number of tax receivables and liabilities increased. If the tax liability is not paid within the deadline, the tax authority must initiate tax execution. On the other hand, the state seeks to increase the efficiency of tax collection, therefore, it is in the interest of the state that taxpayers settle their obligations and claims before the authority starts the lengthy procedures of tax execution. Therefore, we assumed that due to the economic crisis and the need for greater profitability or effectiveness of tax collection, the ZDavP experienced the most changes in relation to tax execution (more on this, Lešnik, 2009, pp. 67-75).

The amending acts aim at improving the tax procedure. On the other hand, the excessive number of adopted amendments can confuse the taxable per- 
sons as they cannot get acquainted with all the changes in time. Thus, the changes can either be positive for the development of the tax procedure or can slow down the interpretation of the law by taxable persons and tax authorities. It needs to be added that the mere changes to articles or to their number are not necessarily the sole indicator of the scope of the changes, as it is possible to change only one article and have a significant effect on all taxes and all taxable persons.

On the basis of the analysis carried out, we can reject the statement that since 1996 the ZDavP has undergone most changes in the field of tax execution; however, if we observe only the general part of the ZDavP, irrespective of the kind of tax, the statement is confirmed.

The acts amending the ZDavP-1 most significantly affected the personal income tax as a result of the requirement to comply with the Personal Income Tax Act (ZDoh-1) and in order to encourage the taxpayers to voluntarily pay taxes, introduce tax reliefs, and simplify administrative procedures. The acts amending the ZDavP-2, just like those amending the ZDavP-1, also introduced changes in the area of personal income tax with the aim of remedying and preventing the consequences of the financial crisis.

It can be concluded from the above that since 1996 when the first ZDavP was adopted and until the adoption of the ZDavP-2, also taking into account the penultimate amending act ZDavP-J adopted in 2016, the Tax Procedure Act experienced the most changes in the area of personal income tax and not in the area of tax execution.

The purpose of the comparison of the development of tax procedure in Sweden was to determine the similarities and the differences in tax procedure development in Sweden and Slovenia and the reasons that led to different developments in tax procedural law. Another purpose was to determine which country was most significant affected by the changes in tax procedural law. Sweden is a highly developed country that has achieved its prosperity only in recent decades. It suffered a major financial crisis in 1991, but picked itself up again to become one of the most developed countries and an inspiration to many EU members. With a highly efficient economy, it ranks among the ten leading countries of the world in terms of national income per capita. This means that it hardly suffered from the financial crisis of 2008, while Slovenia recorded a significant downturn. Norman and McLure (1997) consider the tax reform of 1991 the most far-reaching tax system reform for at least 40 years, making income distribution one of the most important principles of fiscal policy.

According to Lindencrona, G. (2010), tax legislation may be similar in many countries, but the legal environment can often vary due to differences in the legislative process, in the relations between the legislature and the courts, and consequently due to different methods of interpreting tax laws.

Sweden is taken as a model because of its high standard of living and advanced economy. Its tax regime is similar to the Slovenian. They have a tax collecting agency that, unlike the Slovenian FURS, enjoys the respect and trust of 
the Swedish population. The country also adopted specific laws, which form the legal basis for the conditions and methods of collecting taxes. Sweden has already had some tax reforms, raised and reduced tax rates and personal income tax rates, and introduced new taxes with a view to further improving its economic growth.

On the basis of the analysis it can be concluded that Sweden, and Slovenia alike, adopts tax reforms, raises and reduces tax rates and introduces new taxes in order to improve economic growth and increase GDP. Given that both countries are members of the EU (Swede acceded in 1995 but did not introduce the euro), they both need to respect and implement the EU regulations.

Regarding the regulation of tax procedure in Sweden, very few literature and sources were available in English or Slovene, so the comparison of the development of tax procedural law in Sweden was only partial.

The analysis of the judgments of the Administrative, Supreme and Constitutional Courts in tax matters in 2014 and 2015 regarding the incorrect application of substantive law and substantial violation of procedural provisions shows that a large number of actions were dismissed (and hence few actions were granted) as unfounded. In fact, when stating their reasons, the plaintiffs do not substantiate them sufficiently or do not substantiate them at all. Merely stating that the action is based on incorrect application of substantive law or a violation of procedure does not suffice. The fact that a small number of actions in 2014 and 2015 were filed because of erroneous and incomplete determination of facts indicates that the tax authority works well and conducts the procedure in individual cases appropriately.

I believe that the reason why there are far more reviews dismissed by the Supreme Court than granted is that the plaintiffs file unfounded requests, which the Supreme Court dismisses on the basis of Article 92 of the Administrative Dispute Act since no reasons are given for the request and there are no reasons which it needs to take into account ex officio (Article 87 of the Administrative Dispute Act). The parties are likely to request a review although they lack sufficient grounds for the review to get through, as they hope that the Supreme Court will accept their request anyway. By doing so, the parties quite often just fill the court with cases for which it is evident from the outset that they will not be upheld.

The reason why there are not many constitutional complaints filed in tax matters is that a constitutional complaint can be filed only because of a violation of human rights and fundamental freedoms, after all ordinary and extraordinary legal remedies have been exhausted, which means that regular courts perform their work and decide correctly and in accordance with the law, hence the parties have no reason to appeal to the Constitutional Court. In addition, appealing to the Constitutional Court is a lengthy and costly process and many parties refrain from opting for such.

Article 23 of the Constitution of the Republic of Slovenia provides that everyone has the right to have any decision regarding his rights, duties, and any 
charges brought against him made without undue delay by an independent, impartial court constituted by law. Only a judge duly appointed pursuant to rules previously established by law and by judicial regulations may judge such an individual.

The aim of the study was to analyse the judgments of the Administrative, Supreme and Constitutional Courts in tax matters in 2014 and 2015 regarding the incorrect application of substantive law and procedural violation. Incorrect application of substantive law means that substantive law was not applied at all, that an incorrect substantive regulation was applied, that an authority misinterpreted the substantive regulation, or that an authority deciding at discretion exceeded the purpose and extent of discretion. A procedural violation constitutes a substantial violation of procedural provisions. It was assumed that there were more errors related to incorrect application of substantive law than procedural violations, as the authorities and the courts might often misinterpret new or amended provisions or apply the wrong law (e.g. prohibition of retroactivity).

If, in conference or at the hearing, the court of second instance establishes that, in order to enable the full and correct determination of the state of facts, it is necessary to determine the facts claimed by the party and produce the evidence proposed before the court of first instance, which the court of first instance did not determine, or the facts and evidence stated by the party in the complaint, or that the state of facts was incompletely determined due to the incorrect application of substantive law, the court supplements the procedure or eliminates the aforementioned deficiencies and decides with a judgment in the case. If the state of facts was erroneously or incompletely determined due to incorrect application of substantive law and the court assesses, considering the circumstances of the case, that it cannot supplement the procedure or eliminate the aforementioned deficiencies, it rejects the judgment made at first instance and remands the case to the court of first instance for reconsideration (Article 355 of the Contentious Civil Procedure Act).

The analysis covered 223 Administrative Court judgments of 2014 and 174 judgments of 2015 as well as 13 Supreme Court judgments of 2014 and 25 judgments of 2015. The Constitutional Court dealt with one tax-related constitutional complaint in 2014 and one in 2015. In the case of the Constitutional Court, only the constitutional complaints accepted for consideration were taken into account.

The analysis of judgments of the Administrative Court reveals that in 2014 most actions were brought due to substantial violation of procedural provisions, while in 2015 most cases related to incorrect application of substantive law. In both 2014 and 2015, the least actions were brought on grounds of erroneous and incomplete determination of facts. Most of the actions dismissed in 2014 related to substantial violations of procedural provisions, while the least actions dismissed in 2015 related to erroneous and incomplete determination of facts. Most of the actions upheld in 2014 related to 


\section{Tjaša Vozel}

incorrect application of substantive law. In 2015, most of the actions upheld related to substantial violation of procedural provisions.

The analysis of the judgments of the Supreme Court shows that in 2015, the requests for review due to incorrect application of substantive law were mostly dismissed. Also in 2015, most reviews dismissed related to substantial violations of procedural provisions. In 2014, only one review was upheld, namely in relation to the incorrect application of substantive law. In 2015, review was upheld in four cases related to substantial violation of procedure and incorrect application of substantive law.

In the analysis of the judgments of the Constitutional Court, two judgments were examined, one from 2014 and the other one from 2015. The 2014 judgment was upheld and related to substantial violation of procedural provisions, while the 2015 complaint was rejected because the court did not establish incorrect application of substantive law.

The analysis rejected the claim that, according to publicly available court cases by the Administrative, Supreme and Constitutional Courts in tax matters in 2014 and 2015, most errors related to the incorrect application of substantive law rather than procedural violations. The analysis in fact suggested that most errors were found in respect of substantial violations of procedural provisions and that actions were more often upheld in relation to substantial violations of procedure rather than incorrect application of substantive law. It is interesting, however, that actions were mostly brought because of the incorrect application of substantive law, and not because of violation of procedural provisions of procedure.

In order to ensure coherence of the legal and economic systems, tax legislation should not change considerably in a short period of time, especially in terms of a consistent provision of information to the taxpayers about their rights and obligations (Višnjevec, 2007, p. II). The Tax Procedure Act was amended several times, also as a result of the Government programme for the elimination of administrative barriers. The programme simplifies the procedures for the taxpayers and the tax authorities, since the Tax Procedure Act is the key regulation for regulating the relationships between participants in tax collection procedures (Kovač, 2010, p. 99).

It is also necessary to define the problems that repeated changes of laws bring in practice. For example, many reforms had not yet started well when a new minister introduced new reforms (more in Klun, 2006, pp. 7-22). Constant legislative changes are not good, and the Government and the Parliament should be more considerate and reluctant in amending legislation (more in Stanford, 2010). Better regulation is in fact one of the key elements for achieving a competitive economy and establishing an efficient and friendly public administration (more in Jovanović, 2013, pp. 109-120).

Likewise necessary is to carefully examine the impact of constant legislative changes on the population and the authorities, i.e. whether the population and the authorities are able to follow the changes and whether there 
is enough time to adjust to and fully master such. Changes are not necessarily bad, they can even be very positive, necessary, and welcome. They can be evolutionary, taking place within an existing structure, or revolutionary, with deeper changes in the structure. In terms of the speed and pattern of change, changes can be either rare and episodic, or cumulative and continuous changes.

The taxpayers consider the frequent changes all but welcome, as they do not allow a full, coherent and transparent functioning of the tax system as a whole. The situation of the tax system is certainly not encouraging for the economic and societal development and for the transition from a state governed by the rule of law to a social state. Tax legislation should not change much in a short time. This is important to ensure that taxpayers know their rights and obligations. The authorities are striving to minimise the shortcomings and bring the tax system closer to both the addressees of the law and its implementers.

Only time - as well as the practice of the taxpayers on one side and of the tax authorities on the other - will show how the changes will come to life in practice and whether the objectives regarding the simplification of the tax collection process and the reduction of administrative burdens will be achieved.

\section{Conclusion}

It is necessary to carefully examine the impact of constant legislative changes on the population and the authorities, i.e. whether the population and the authorities are able to follow the changes and whether there is enough time to adjust to and fully understand such.

The taxpayers consider the frequent changes all but welcome, as they do not allow a full, coherent and transparent functioning of the tax system as a whole. The situation of the tax system is certainly not encouraging for the economic and societal development and for the transition from a state governed by the rule of law to a social state. Tax legislation should not change much in a short time. This is important to ensure that taxpayers know their rights and obligations. The authorities are striving to minimise the shortcomings and bring the tax system closer to both the addressees of the law and its implementers.

Only time - as well as the practice of the taxpayers on one side and of the tax authorities on the other - will show how the changes will come to life in practice and whether the objectives regarding the simplification of the tax collection process and the reduction of administrative burdens will be achieved.

The principles of the tax procedure will undoubtedly contribute to the objectives of the new law. As always, however, also in this case, the actual value of the legislative provisions will only be created by administrative and judicial practice. 


\section{Tjaša Vozel}

The analysis rejected the claim that, according to publicly available court cases by the Administrative, Supreme and Constitutional Courts in tax matters in 2014 and 2015, most errors related to the incorrect application of substantive law rather than procedural violations. The analysis in fact suggested that most errors were found in respect of substantial violations of procedural provisions and that actions were more often upheld in relation to substantial violations of procedure rather than incorrect application of substantive law. It is interesting, however, that actions were mostly brought because of the incorrect application of substantive law, and not because of violation of procedural provisions of procedure.

The results of the research can be used for drafting future acts amending the ZDavP-2, or possibly even a completely new Tax Procedure Act. The Master's thesis will contribute to administrative-legal science and the tax profession. With this article, the reader will obtain an insight into the development of the Tax Procedure Act in Slovenia.

The research will also benefit the tax profession, because the article presents the advantages and disadvantages of the development and changes in the tax procedure to date. The analysis of the judgments of the Administrative, Supreme and Constitutional Courts will contribute to the understanding of how the ZDavP-2 is applied in practice, whether it is properly interpreted by the tax authorities and the courts, and how the Constitutional Court contributes to case law through judgments concerning the incorrect application of substantive law or procedural violations. The research covers multi- or interdisciplinary aspects of public management of law, economics, and informatics. 


\section{References}

Act Amending the Tax Procedure Act (ZDavP-A). (1997). Official Gazette of RS, No. 87/97.

Act Amending the Tax Procedure Act (ZDavP-B). (1998). Official Gazette of RS, No. 82/98.

Act Amending the Tax Procedure Act (ZDavP-1A). (2004). Official Gazette of RS, No. 139/04.

Act Amending the Tax Procedure Act (ZDavP-1B). (2005). Official Gazette of RS, No. $109 / 05$.

Administrative Dispute Act (ZUS-1). (2006). Official Gazette of RS, No. 105/06.

Act Amending the Tax Procedure Act (ZDavP-2A). (2008). Official Gazette of RS, No. 125/08.

Act Amending the Tax Procedure Act (ZDavP-2B). (2009). Official Gazette of RS, No. 110/09.

Act Amending the Tax Procedure Act (ZDavP-2C). (2010). Official Gazette of RS, No. 43/10.

Act Amending the Tax Procedure Act (ZDavP-2D). (2010). Official Gazette of RS, No. 97/10.

Act Amending the Tax Procedure Act (ZDavP-2E). (2012). Official Gazette of RS, No. 32/12.

Act Amending the Tax Procedure Act (ZDavP-2F). (2012). Official Gazette of RS, No. 94/12.

Act Amending the Tax Procedure Act (ZDavP-2G). (2013). Official Gazette of RS, No. 111/13.

Act Amending the Tax Procedure Act (ZDavP-2H). (2014). Official Gazette of RS, No. 90/14.

Act Amending the Tax Procedure Act (ZDavP-2I). (2015). Official Gazette of RS, No. 91/15.

Act Amending the Tax Procedure Act (ZDavP-2K). (2017). Official Gazette of RS, No. 69/17.

Act Amending the Public Finance Act (ZJF-H). (2018). Official Gazette of RS, No. $13 / 18$

Androjna, V. and Kerševan, E. (2006). Upravno procesno pravo: upravni postopek in upravni spor. Ljubljana: IUS Software, GV Založba.

Constitution of the Republic of Slovenia (URS). (1991). Official Gazette of RS, No. 33/91-I, 42/97 - UZS68, 66/00 - UZ80, 24/03 - UZ3a, 47, 68, 69/04 - UZ14, 69/04 - UZ43, 69/04 - UZ50, 68/06 - UZ121,140,143, 47/13 - UZ148 and 47/13 - UZ90,97,99.

Constitutional Court Act (ZUstS ). (1994). Official Gazette of RS, No. 15/94, 51/07, 109/12.

Contentious Civil Procedure Act (ZPP). (1999). Official Gazette of RS, No. 26/99.

Corrigendum to the Act Amending the Tax Procedure Act (ZDavP-2B). (2010). Official Gazette of RS, No. 1/10.

General Administrative Procedure Act (ZUP). (2006). Official Gazette of RS, No. 24/06, 105/06 - ZUS-1, 126/07, 65/08, 8/10 and 82/13.

Jerovšek, T., Simič, I., Škof, B. et al. (2008). Zakon o davčnem postopku s komentarjem. Ljubljana: Davčno izobraževalni inštitut. 


\section{Tjaša Vozel}

Jovanović, T. (2013). Ali je bil reformni ukrep Slovenije iz leta 2012 na področju davčne zakonodaje za mikro podjetja učinkovit? Mednarodna revija za javno upravo, 11(2), pp. 109-120.

Klun, M. (2006). Does the competition make tax reform essential? Uprava, 4(2-3), pp. 7-22.

Kovač, P., Remic, M. and Sever, T. (2015). Upravno-procesne dileme 3 v posebnih upravnih postopkih: 90 vprašanj z odgovori, sodno prakso in uvodno študijo o enakem varstvu pravic na področjih socialne varnosti, šolstva, prostora in gradenj, notranjih zadev ter davčnega in inšpekcijskega nadzora. Ljubljana: Uradni list Republike Slovenije.

Kovač, P. (2010). Zakon o davčnem postopku v okviru odprave administrativnih ovir - med cilji in prakso. Uprava, 8(1-2), pp. 99-122.

Lamut, S. (2016). Katere pomembne novosti nam prinašajo spremembe in dopolnitve Zakona o davčnem postopku z novelo ZDavP-2J? Davčno-finančna praksa, 17(11), pp. 8-10.

Lešnik, T. (2009). Učinkovitost davčne izvršbe v Sloveniji - Pregled v obdobju od 2000 do 2007. IB revija: za strokovna in metodološka vprašanja gospodarskega, prostorskega in socialnega razvoja Slovenije, 43(2), pp. 67-75.

Lindencrona, G. (2010). Unique features in Swedish Tax Law. At <http://www. scandinavianlaw.se/pdf/50-11.pdf>, accessed 10 February 2016.

Lodin, S. (2011). The Making of Tax Law: The Development of the Swedish Tax System. Amsterdam: IBFD.

Norman, E. and McLure, C. E. Jr. (1997). Tax Policy in Sweden. Chicago: University of Chicago Press, pp. 109-154.

Odločba Ustavnega sodišča RS. (2014). Up-879/12 in U-I-234/12. At <http:// odlocitve.us-rs.si/sl/odlocitev/US30393?q=ZDavP\&sort=date\&order=desc>, accessed 1 March 2016.

Sodna praksa (2013). User manual. At <http://sodnapraksa.si/ navodila_html/ISKALNIK_Navodila_za_uporabo_exported_10-38-01. html\#kajjesodnapraksa>, accessed 10 December 2016.

Stanford, C. (2009). Successful Tax Reform. Great Britain: Fiscal Publications.

Šinkovec, J. and Tratar, B. (2002). Zakon o davčnem postopku s komentarjem. Lesce: Oziris.

Tax Procedure Act (ZDavP). (1996). Official Gazette of RS, No. 18/96, 87/97, 35/98 - CC dec., 82/98, 91/98, 1/99 - ZNIDC, 108/99, 37/01 - CC dec., 97/01, 105/03 - CC dec., 16/04 - CC dec. and 54/04.

Tax Procedure Act (ZDavP-1). (2004). Official Gazette of RS, No. 21/, 58/06 corrig. and 117/06.

Tax Procedure Act (ZDavP-2). (2006). Official Gazette of RS, No. 117/06.

Terra, B. J. M. and Wattel, P. J. (2012). European tax law. Alphen aan den Rijn: Kluwer Law International.

Treaty on the Functioning of the European Union (TFEU). (2012). Consolidated version. UL C 326/1, 26 October 2012.

Višnjevec, K. (2007). Davčni inšpekcijski postopek - novosti v novem ZDavP-2. Pravna praksa, 26 (10), App. pp. II-VI.

Vozel, T. (2017). Razvoj davčnega procesnega prava in področne judikature v izbranih državah: magistrsko delo. Fakulteta za upravo. 